\title{
Follow up investigation of workers in synthetic fibre plants with humidifier disease and work related asthma
}

\author{
Teake M Pal, Jan G R de Monchy, Johan W Groothoff, Doeke Post
}

\begin{abstract}
Objective-To investigate the clinical and sociomedical outcome in patients with various clinical manifestations of humidifier disease and work related asthma after removal from further exposure.

Methods-Follow up investigation (range 1-13 years) of respiratory symptoms, spirometry, airway responsiveness, sickness absence, and working situation in patients with (I) humidifier fever $(n=12)$, (II) obstructive type of humidifier lung $(n=8)$, (III) restrictive type of humidifier lung $(n=4)$, and (IV) work related asthma $(n=22)$. All patients were working at departments in synthetic fibre plants with microbiological exposure from contaminated humidification systems or exposure to small particles $(<1 \mu \mathrm{m})$ of oil mist.
\end{abstract}

Results-At follow up patients with work related asthma were less often symptom free $(37 \%, 7 / 19)$ than patients with humidifier disease (I, II, III) $(67 \%, 16 / 24)$. Mean forced expiratory volume in one second $\left(F E V_{1}\right)$ of patients with obstructive impairment had been increased significantly at follow up but still remained below the predicted value. Mean forced vital capacity (FVC) of patients with initially restrictive impairment had returned to normal values at follow up. Airway hyperresponsiveness at diagnosis persisted in patients with obstructive impairment (II+IV 14/17, but disappeared in patients with humidifier fever (3/3) and restrictive type of humidifier lung (2/2). In patients with obstructive impairment (II+IV), FVC and $\mathrm{FEV}_{1}$ at diagnosis were negatively associated with the duration between onset of symptoms and diagnosis and the number of years of exposure. Those with positive pre-employment history of respiratory disease had a lower $\mathrm{FEV}_{1}$ at diagnosis. Sickness absence due to respiratory symptoms decreased in all groups of patients after removal from further exposure, but this was most impressive in patients with the humidifier lung (II, III) and patients with work related asthma (IV). At follow up $83 \%$ of the patients were still at work at the same production site, whereas $11 \%$ received a disability pension because of respiratory disease.

Conclusion-In patients with work related respiratory disease caused by exposure from contaminated humidification systems or oil mist, removal from further exposure resulted in clinical improvement, although, especially in those with obstructive impairment, signs persisted. Because of the possibility of transferring patients to exposure-free departments most patients could be kept at work. (Occup Environ Med 1999;56:403-410)

Keywords: humidifier disease; work related asthma; follow up

Between 1975 and 1990 the Occupational Health Department of a large production site with different synthetic (nylon, polyester) fibre plants was regularly faced with the occurrence of work related respiratory symptoms in workers of different departments; although the departments had some similarities. They were characterised by microbiological exposure caused by contaminated humidification systems or exposure to small sized particles $(<1$ $\mu \mathrm{m})$ of oil mist, which mostly resulted from heating and stretching the yarn after an oil mixture had been applied.

The patients could be divided into different groups. Some workers had symptoms and signs of inhalation fever (humidifier fever); in a small group extrinsic allergic alveolitis or occupational asthma caused by humidifier antigens (humidifier lung) was diagnosed. More patients had features of work related asthma. The term work related asthma instead of occupational asthma for this group has been used because it was not always clear if exposure had functioned as an inciter or as an inducer. ${ }^{1}$ Moreover, in these patients the causal role of contaminated humidification systems did not become clear because specific skin tests, serology, or specific inhalation challenges with humidifier antigens had not been performed.

We have previously published the clinical data of patients within this group with humidifier disease, ${ }^{2}$ and data about lung function, white blood cell counts, skin tests, and serology in exposed workers. ${ }^{3}$

After diagnosing work related respiratory disease there is usually a need for taking remedial action. Patients have to be removed from the suspected exposure, and exposure conditions have to change to prevent the occurrence of new cases among the other exposed workers. Both types of intervention were carried out and we were interested in their effects in the different groups of patients and other exposed workers.

In this paper we present follow up data of the patients, both clinical (symptoms, and lung function) and sociomedical (sickness absence, disability, and employment status). To our 
knowledge this is the first follow up study describing the full range of humidifier disease occurring within one production site.

\section{Methods}

STUDY POPULATION

The patients were derived from a register of workers with work related respiratory symptoms, kept up by the occupational health department of the synthetic fibre production site. Only patients were included who, when they reported their symptoms, were working at departments with contaminated humidification systems or exposure to oil mist.

We divided the patients into two main groups: (1) patients with established or most likely humidifier disease $(\mathrm{n}=24 \mathrm{I}, \mathrm{II}, \mathrm{III})$; and (2) patients with work related asthma ( $\mathrm{n}=22$ IV). Patients with humidifier disease were subdivided into: (I) a humidifier fever group ( $\mathrm{n}=12)$; (II) an obstructive humidifier lung group ( $\mathrm{n}=8)$; and (III) a restrictive humidifier lung group $(n=4)$. Inclusion criteria for the humidifier disease group were:

- The reporting of work related respiratory symptoms combined with feelings of general illness (fever, myalgia) and $>2000 / \mathrm{mm}^{3}$ increase of white blood cell count, which is more than the average diurnal change $+3 \mathrm{SD}$, after inhalation challenge by natural exposure at work. ${ }^{5}$

- The reporting of work related respiratory symptoms, and $>20 \%$ decrease of peak flow, or $10 \%$ decrease of forced vital capacity (FVC), or forced expiratory volume in one second $\left(\mathrm{FEV}_{1}\right)$ during workplace inhalation challenge combined with positive skin tests and serology on humidifier antigens.

- The reporting of work related respiratory symptoms combined with restrictive lung function, positive skin tests, and serology on humidifier antigens.

- The reporting of work related respiratory symptoms combined with a positive clinical inhalation challenge with humidifier antigens.

Various patients fulfilled more than one of the inclusion criteria.

Patients were classified into: (I) the humidifier fever group when they had normal spirometry values before workplace inhalation challenge and reacted to challenge with an increase of white blood cell count $(>2000$ $\mathrm{mm}^{3}$ ), with or without decrease of peak-flow $(>20 \%)$, or a decrease in FVC or $\mathrm{FEV}_{1}$ $(>10 \%)$; (II) the obstructive humidifier lung group when their prechallenge spirometry values were already indicative of obstruction $\left(\mathrm{FEV}_{1}<80 \%\right.$ predicted, $\mathrm{FEV}_{1} / \mathrm{FVC}<70 \%$ predicted) and they reacted on challenge with a greater decrease in $\mathrm{FEV}_{1}$ than FVC; (III) the restrictive humidifier lung group when their prechallenge spirometry values were already indicative of restriction (both $\mathrm{FVC}$ and $\mathrm{FEV}_{1}$ $<80 \%$ predicted and $\mathrm{FEV}_{1} / \mathrm{FVC}>70 \%$ predicted).

The second main group, with work related asthma, (IV) consisted of 22 patients with work related respiratory symptoms, however, not associated with feelings of general illness. They had no signs of restrictive lung function.
During workplace inhalation challenge in these patients peak flow or spirometry have been followed up, but not temperature and white blood cell counts. There were no data on skin tests or serology in the challenge period. This means that in this group too there could have been some patients with the obstructive type of humidifier disease.

\section{DATA GATHERING}

From the medical records of the patients present in the occupational health department, the following data were derived:

- Data of pre-employment examination for history of respiratory symptoms and atopic symptoms

- Period between start of (work related) respiratory symptoms and intervention (lag time)

- The duration of the follow up period

- Smoking habits and spirometry data at the moment of diagnosis

- Data on workplace inhalation challenge

- Data on skin tests, serology, and clinical inhalation with humidifier antigens

- Data on skin tests with standard allergens

- Sickness absence (calendar days $\times 100 /$ 365) due to respiratory symptoms in the period between the first reporting of (work related) respiratory symptoms and intervention and in the follow up period after intervention

- Working situation at the time of follow up.

Patients who were still at work at the time of follow up were invited for a follow up investigation consisting of filling in a modified Dutch version of the British MRC standardised questionnaire, spirometry, and assessing airway responsiveness by a histamine challenge test according to a modified version of the De Vries protocol. ${ }^{6}$ The histamine threshold was defined as the concentration at which the subject would have experienced or has experienced a fall in $\mathrm{FEV}_{1}$ of $\geqslant 20 \%$. For some patients who had left the plant at the moment of the follow up investigation, data on spirometry after intervention were derived from their medical records.

\section{STATISTICAL ANALYSIS}

Spirometry results were expressed as percentage predicted. Changes in spirometry at follow up compared with data at the moment of diagnosis were tested by paired Student's $t$ test. In the patient groups II and IV (obstructive airways) the relation with spirometry at diagnosis and spirometry changes at follow up of the variables pre-employment history, atopy, lag time, and duration of exposure were tested both by univariate (unpaired Student's $t$ test, analysis of variance (ANOVA)) and in a multivariate lineair regression model. For this analysis lag time and duration of exposure were categorised into three subclasses:

Lag time: $\leqslant 6$ months, $7-24$ months, $\geqslant 24$ months.

Duration of exposure (y): $\leqslant 1 \mathrm{y}, 2-5 \mathrm{y}, \geqslant 5 \mathrm{y}$.

In the multivariate linear regression model the classification smoking (smokers, nonsmokers) was also included. Differences in nominative data were tested by $\chi^{2}$ test. Analyses 
Table 1 Characteristics of synthetic fibre plant workers with humidifier disease and work related asthma 1975-90

\begin{tabular}{|c|c|c|c|c|}
\hline \multirow[b]{4}{*}{ Patients (n) } & \multicolumn{3}{|l|}{ Humidifier disease } & \multirow{3}{*}{$\begin{array}{l}\text { IV Work } \\
\text { related asthma }\end{array}$} \\
\hline & \multirow[b]{2}{*}{ I Humidifier fever } & \multicolumn{2}{|l|}{ Humidifier lung } & \\
\hline & & II Obstructive defect & III Restrictive defect & \\
\hline & 12 & 8 & $4 \quad(1$ ㅇ) & $22(2 \circ)$ \\
\hline Age (range) & $29.8(22-44)$ & $40 \quad(20-53)$ & $45.3(39-49)$ & $32.2(21-55)$ \\
\hline Smokers (\%) & $5 \quad(42)$ & $6 \quad(75)$ & 0 & $15 \quad(68)$ \\
\hline Non-smokers (\%) & $7 \quad(58)$ & $2(25)$ & $4 \quad(100)$ & $7 \quad(32)$ \\
\hline History or signs of atopy (\%) & $1 \quad(8)$ & $5 \quad(62.5)$ & 0 & $7 \quad(44)^{\star}$ \\
\hline $\begin{array}{l}\text { Pre-employment history of respiratory } \\
\text { problems }(\%)\end{array}$ & $1 \quad(8)$ & $3 \quad(37.5)$ & 0 & $8 \quad(36)$ \\
\hline $\begin{array}{l}\text { Years of employment at humidifier } \\
\text { department (range) }\end{array}$ & $4.2(0.25-10)$ & $5.1(0.25-10)$ & $5.8(2-11)$ & $5.5(0.25-26)$ \\
\hline $\begin{array}{l}\text { Period between start of symptoms and } \\
\text { intervention (range, months) }\end{array}$ & $5.5(1-15)$ & $15.3(1-72)$ & $9.3(3-17)$ & $27.9(0.5-84)$ \\
\hline Sickness absence & 3 & 5 & 2 & 12 \\
\hline Free consultation & 8 & 3 & 1 & 8 \\
\hline $\begin{array}{l}\text { Referral (general practitioner, } \\
\text { clinician) }\end{array}$ & 1 & & 1 & 2 \\
\hline
\end{tabular}

^No atopy data for six patients.

$\dagger \mathrm{n}=19$.

Table 2 Follow up data after intervention in workers of synthetic fibre plants with humidifier disease and work related asthma, 1975-90

\begin{tabular}{|c|c|c|c|c|}
\hline & \multicolumn{3}{|l|}{ Humidifier disease } & \multirow{3}{*}{$\begin{array}{l}\text { IV Work related } \\
\text { asthma }\end{array}$} \\
\hline & \multirow[b]{2}{*}{ I Humidifier fever } & \multicolumn{2}{|l|}{ Humidifier lung } & \\
\hline & & II Obstructive defect & III Restrictive defect & \\
\hline Patients (n) & 12 & 8 & 4 & 22 \\
\hline Symptom free & 8 & 5 & 3 & $7+$ \\
\hline Daily medication & 0 & 3 & 1 & 8 \\
\hline \multicolumn{5}{|c|}{ FVC $\%$ predicted $(\mathrm{SD}):$} \\
\hline At diagnosis & 99 (11.9) & $91.1(15.0)^{\star}$ & $77.8(16.5)^{\star \star}$ & $95.7(13.2)$ \\
\hline At follow up & $99(16.4)$ & $106.7(15.2) \ddagger$ & $103.3(8.0)$ & $96.0(13.8) \dagger$ \\
\hline \multicolumn{5}{|c|}{$\mathrm{FEV}_{1} \%$ predicted (SD): } \\
\hline At diagnosis & $96(95)$ & $71.4(13.0)^{\star \star}$ & $75.3(16.1)^{\star}$ & $78.1(16.1)^{\star}$ \\
\hline At follow up & $98(16.6)$ & $86.7(13.2) \ddagger$ & $99.7(3.1)$ & $83.5(19.8) \dagger$ \\
\hline \multicolumn{5}{|c|}{ Working situation at follow up: } \\
\hline Same department & 2 & & & 1 \\
\hline Transferred & 10 & 4 & 3 & 18 \\
\hline Disabled & & 4 & 1 & 2 \\
\hline Resigned & & & & 1 \\
\hline
\end{tabular}

${ }^{\star} \mathrm{p}<0.05 ;{ }^{\star \star} \mathrm{p}<0.01$.

†Follow up data in 19 patients.

$\ddagger$ Follow up spirometry in seven patients.

were performed with SAS (statistical analysis system version 6.09).

\section{Results}

Table 1 summarises some characteristics of the patient groups. All patients with humidifier fever worked at a relatively new department which explains their low mean age.

Most patients within the work related asthma group and the humidifier lung subgroup with an obstructive defect were smokers. By contrast, all patients with humidifier lung and a restrictive defect were non-smokers. Both patient groups (II and IV) with the obstructive type disease had the highest prevalence of history or signs of atopy and positive pre-employment history of respiratory problems.

Years of employment corresponded with years of exposure to oil mist but it is not certain if this was also the case with duration of exposure to humidifier antigen. The period between the start of symptoms and the intervention was shortest in the humidifier fever group with a relatively small range, especially compared with the two groups of patients with obstructive airway disease. The medical records showed that the first signal of work relateness in the humidifier fever group was mostly presented at the free consultation hour, whereas work relateness in the other groups of patients was usually suspected because of sickness absence.

Data on the workplace inhalation challenge in the patients are only given in summary here. In those with humidifier disease, an increase $\left(>2000 / \mathrm{mm}^{3}\right)$ of white blood cell count proved to be the most sensitive variable with a positive reaction in $86 \%$ of the patients. Patients with the restrictive type of humidifier lung did not react with a significant decrease in spirometry during one working week, but showed gradual improvement after a longer period free from exposure.

In the patients with work related asthma workplace inhalation challenge was performed in all but one. The reaction in 14 patients was considered as positive because they showed a peak flow decrease $>20 \%$ or a decrease in $\mathrm{FEV}_{1}$ $>10 \%$ during a challenge week. In four patients the reaction was less clear and in three patients no significant decrease of peak flow or $\mathrm{FEV}_{1}$ was found during a challenge day or challenge week. This means that these seven patients 


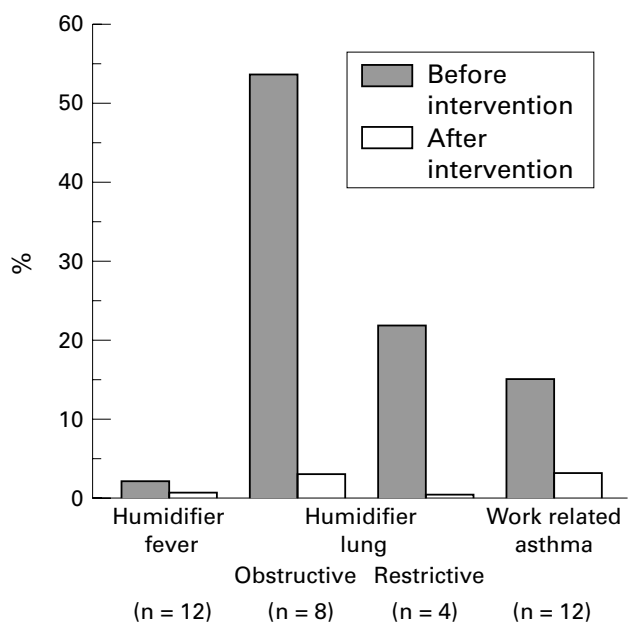

Sickness absence due to respiratory symptoms (\% of calender days) in the period between first reporting of (work related) respiratory symptoms and intervention and in the follow up period after intervention.

belonged to the work related asthma group only because of their reporting of work related respiratory symptoms.

Follow up data are presented in table 2.

Most patients with humidifier disease (I, II, III) were free of respiratory symptoms at follow up $(67 \% 16 / 24)$ whereas in the group with work related asthma (IV) this was only the case in $37 \%(7 / 19)$ of the patients $(\mathrm{p}<0.05)$. At follow up, patients with an obstructive defect (II+IV) more often reported $(\mathrm{p}<0.05)$ needing daily medication than did patients with humidifier fever and the restrictive type of humidifier lung (I+III) $(11 / 27 v 1 / 16)$. In both workers with humidifier lung and work related asthma spirometry showed better results at follow up than at diagnosis by contrast with the workers with humidifier fever who had normal values both at diagnosis and follow up.

The mean FVC and $\mathrm{FEV}_{1}$ of patients with a restrictive defect was not different from the predicted value at follow up. Although in both groups of patients with an obstructive defect mean $\mathrm{FEV}_{1}$ at follow up was significantly higher than at diagnosis it still remained below the predicted value. Sickness absence due to respiratory symptoms sharply declined after intervention in the workers with humidifier lung and work related asthma (figure). Sickness absence due to respiratory symptoms before intervention was already low in the humidifier fever group but it also declined, although less strikingly.

At follow up $83 \%$ of the patients were still at work. Most patients had been transferred to another department. Two patients with humidifier fever returned to their original department after modification of the humidification

Table $3 \quad F V C \%$ predicted and $F E V_{1} \%$ predicted at diagnosis and $\triangle F V C \%$ predicted and $\triangle F E V_{1} \%$ predicted at follow up after removal from exposure in workers with obstructive type of humidifier disease (II) and work related asthma (IV)

\begin{tabular}{|c|c|c|c|c|}
\hline & \multicolumn{2}{|l|}{ Diagnosis } & \multicolumn{2}{|l|}{ Follow-up } \\
\hline & $\begin{array}{l}F V C \% \text { predicted } \\
(S D)\end{array}$ & $\begin{array}{l}F E V_{1} \% \text { predicted } \\
(S D)\end{array}$ & $\begin{array}{l}\triangle F V C \% \text { predicted } \\
(S D)\end{array}$ & $\begin{array}{l}\triangle F E V_{1} \% \text { predicted } \\
(S D)\end{array}$ \\
\hline \multicolumn{5}{|c|}{ Pre-employment history of respiratory disease: } \\
\hline Negative $(n=19)$ & $98.6(12.4)$ & $80.6(17.3)$ & $2.5(17.9)(n=15)$ & $6.6(16.1)$ \\
\hline Positive $(n=11)$ & $90.2(16.3)$ & $71.9(15.6)$ & $7.9(8.5)$ & $10.5(8.0)$ \\
\hline \multicolumn{5}{|c|}{ History or signs of atopy: $†$} \\
\hline Negative $(n=10)$ & $96.9(16.5)$ & $75.4(20.0)$ & $0.7(17.5)$ & $4.6(13.0)$ \\
\hline Positive $(n=14)$ & $92.1(14.1)$ & $73.8(14.2)$ & $10.4(16.1)$ & $11.9(12.5)$ \\
\hline \multicolumn{5}{|l|}{ Lag time (months): } \\
\hline$\leqslant 6(n=9)$ & $94.2(14.5)$ & $77.4(16.5)$ & $11.4(16.1)(\mathrm{n}=8)$ & $13.8(11.0)$ \\
\hline $7-24(n=10)$ & $104.7(10.4)^{\star}$ & $85.3(17.5)$ & $2.6(15.8)$ & $9.9(13.3)$ \\
\hline$\geqslant 24(\mathrm{n}=11)$ & $88.3(13.5)$ & $70.3(14.9)$ & $-0.4(12.0)$ & $2.7(13.6)$ \\
\hline \multicolumn{5}{|c|}{ Duration of exposure (y): } \\
\hline$\leqslant 1(n=13)$ & $93.4(13.9)$ & $77.0(15.1)$ & $3.7(16.8)$ & $9.2(15.3)$ \\
\hline $2-5(n=7)$ & $103.1(11.2)$ & $85.3(19.1)$ & $0.0(3.5)(n=5)$ & $4.0(7.0)$ \\
\hline$\geqslant 5(n=10)$ & $93.1(16.1)$ & $72.5(17.5)$ & $9.4(15.4)(\mathrm{n}=8)$ & $9.3(13.2)$ \\
\hline
\end{tabular}

${ }^{\star} \mathrm{p}<0.05$.

†No atopy classification in six patients.

Lag time=time between start of symptoms and diagnosis.

Table 4 Adjusted regression coefficients (SEM) for FVC\% predicted and FEV \% predicted at diagnosis and $\triangle F V C \%$ predicted and $\triangle F E V_{1} \%$ predicted in patients $(n=24)$ with the obstructive type of humidifier disease (II) and work related asthma (IV)

\begin{tabular}{|c|c|c|c|c|}
\hline & \multicolumn{2}{|l|}{ Diagnosis } & \multicolumn{2}{|l|}{ Follow up } \\
\hline & $\begin{array}{l}F V C \% \text { predicted } \\
(S D)\end{array}$ & $\begin{array}{l}F E V_{i} \% \text { perdicted } \\
(S D)\end{array}$ & $\begin{array}{l}\triangle F V C \% \text { perdicted } \\
(S D)\end{array}$ & $\begin{array}{l}\triangle F E V_{1} \% \text { perdicted } \\
(S D)\end{array}$ \\
\hline \multicolumn{5}{|l|}{ Pre-employment history of } \\
\hline History or signs of atopy & $-2.174(3.976)$ & $-0.651(6.034)$ & $8.284(7.046)$ & $3.702(7.135)$ \\
\hline \multicolumn{5}{|l|}{ Lag time (months) } \\
\hline$\leqslant 6$ & $3.514(4.644)$ & $3.354(7.201)$ & $12.618(7.293)$ & $9.174(7.385)$ \\
\hline $7-24$ & $21.718(4.792)^{\star}$ & $25.018(6.710)^{\star}$ & $-1.264(10.082)$ & $7.824(10.210)$ \\
\hline$\geqslant 24$ & 0.0 & 0.0 & 0.0 & 0.0 \\
\hline \multicolumn{5}{|l|}{ Duration of exposure (y): } \\
\hline$\leqslant 1$ & $-4.832(4.104)$ & $12.232(7.415)$ & $-7.989(7.378)$ & $-5.231(7.472)$ \\
\hline $2-5$ & $15.920(5.240)^{\star}$ & $40.286(9.204)^{\star}$ & $-13.794(9.993)$ & $-7.573(10.120)$ \\
\hline$\geqslant 5$ & 0.0 & 0.0 & 0.0 & 0.0 \\
\hline Smoking & $4.251(5.575)$ & $-19.161(5.562)$ & $-5.067(10.027)$ & $-5.098(10.154)$ \\
\hline
\end{tabular}

${ }^{\star} \mathrm{p}<0.05$.

Lag time=time between start of symptoms and diagnosis. 
Table 5 Airway responsiveness in workers of synthetic fibre plants with humidifier disease and work related asthma, 1975-90 at diagnosis and at follow up after removal from further exposure

\begin{tabular}{|c|c|c|c|c|}
\hline & \multicolumn{3}{|c|}{ Humidifier disease } & \multirow[b]{3}{*}{$\begin{array}{l}\text { IV Work related } \\
\text { asthma }(n=22)\end{array}$} \\
\hline & \multirow[b]{2}{*}{$\begin{array}{l}\text { I Humidifier } \\
\text { fever }(n=12)\end{array}$} & \multicolumn{2}{|c|}{ Humidifier lung } & \\
\hline & & $\begin{array}{l}\text { II Obstructive } \\
\text { defect }(n=8)\end{array}$ & $\begin{array}{l}\text { III Restrictive } \\
\text { defect }(n=4)\end{array}$ & \\
\hline \multicolumn{5}{|l|}{ Patients tested $(\mathrm{n})$ : } \\
\hline At diagnosis & 111 & 8 & 3 & 18 \\
\hline At follow up & 9 & 3 & 2 & 14 \\
\hline \multicolumn{5}{|l|}{ At diagnosis : } \\
\hline Histamine threshold $\leqslant 32 \mathrm{mg} / \mathrm{ml}$ & 3 & 7 & 2 & 16 \\
\hline \multicolumn{5}{|l|}{ At follow up : } \\
\hline Histamine threshold $\uparrow$ & 3 & 1 & 2 & 4 \\
\hline Histamine threshold $\downarrow$ & 1 & 2 & & 4 \\
\hline Histamine threshold $\equiv$ & 5 & & & 6 \\
\hline Histamine threshold $\leqslant 32 \mathrm{mg} / \mathrm{ml}$ & 1 & 2 & & 13 \\
\hline \multicolumn{5}{|c|}{ Follow up in patients with histamine threshold $\leqslant 32 \mathrm{mg} / \mathrm{ml}$ at diagnosis: } \\
\hline Histamine threshold $\uparrow$ & 3 & 1 & 2 & 4 \\
\hline Histamine threshold $\downarrow$ & & 2 & & 5 \\
\hline Histamine threshold $\equiv$ & & 0 & & 4 \\
\hline Histamine threshold $\leqslant 32 \mathrm{mg} / \mathrm{ml}$ & & 2 & & 12 \\
\hline No data & & 4 & & 3 \\
\hline
\end{tabular}

system. One patient with work related asthma stayed at his department.

At the time of the follow up seven patients received a disability pension and did not work (table 2$)$; in five of them $(11 \% 5 / 46)$ the work related lung disease was the main cause of disability.

Within patient groups II and IV (obstructive patients) the association between spirometry at diagnosis and the change at follow up and several patient characteristics was analysed by both univariate (table 3) and multivariate (table 4) analyses. The univariate analyses showed a significant association between classification of lag time and $\mathrm{FVC} \%$ predicted at diagnosis (table 3). This was confirmed in the multiple linear regression analysis which could be performed with the data of 24 patients. This analysis also showed significant associations between a positive pre-employment history of respiratory disease, classification of lag time, years of exposure, and $\mathrm{FEV}_{1} \%$ predicted at diagnosis (table 4). Although patients with a lag time $\geqslant 24$ months and $\geqslant 5$ years of exposure had the lowest FVC and $\mathrm{FEV}_{1}$, their spirometry was most different from those with a lag time of 7-24 months and 2-5 years of exposure, but the difference with patients with less lag time and number of exposure years was not significant.

Both in univariate and multivariate analyses there were no significant associations between changes in FVC and changes in $\mathrm{FEV}_{1}$ and the various characteristics of the patients. Analysis performed with only the data of patients with work related asthma (IV) showed the same results.

In most patients airway responsiveness was tested at diagnosis. However, we did not have the opportunity to retest all those patients again at the follow up (table 5).

Increased airway responsiveness (histamine threshold $\leqslant 32 \mathrm{mg} / \mathrm{ml}$ ) at diagnosis occurred in only $27 \%(3 / 11)$ of the tested patients with humidifier fever, but in $87.5 \%(7 / 8)$ of group II and $89 \%(16 / 18)$ of group IV with diagnosed obstructive disease. Also two out of three patients with a restrictive defect tested had increased airway responsiveness. All three patients with humidifier fever who had increased airway responsiveness at diagnosis showed improvement at follow up to the normal value $(>32 \mathrm{mg} / \mathrm{ml})$. In one patient with humidifier fever and normal responsiveness at diagnosis, the histamine threshold was lower at follow up.

The two patients with a restrictive defect who were hyperresponsive at diagnosis, had a normal threshold at follow up. In the patients with obstructive airway disease (II+IV) both improvement and worsening of responsiveness was noticed at follow up. However, most of the retested patients $(15 / 17,88 \%)$ were still hyperresponsive (table 5 ). There were no differences in changes of hyperresponsiveness when patients with a positive pre-employment respiratory history were compared with patients with a negative history or when patients with atopic signs or symptoms were compared with patients who were not atopic. Two out of the seven patients within the work related asthma group, who reported at follow up that they were free of respiratory symptoms, showed a clear increase in airway responsiveness.

\section{Discussion}

In this study we wanted to investigate follow up after intervention in patients with work related respiratory disease working at different synthetic fibre plants with contaminated humidification systems and exposure to oil mist.

As outcome variables we distinguished clinical symptoms (spirometry, airway responsiveness) and sociomedical symptoms (sickness absence, disability, and working situation).

Removal from further exposure was the first measure in all but one patient after establishing diagnosis.

Because remedial actions took place to clean the humidifier systems after an outbreak of humidifier disease some patients could have returned to their original workplace. Only in two patients in the humidifier fever group had this occurred. Most patients were transferred to another department, sometimes within the same plant.

Generally speaking, the follow up data show an encouraging picture: disappearance of 
respiratory symptoms, improvement of spirometry, decrease of sickness absence, and most $(83 \%)$ of the patients were still at work. However, between the patient groups and within the group with obstructive impairment (II+IV) the data were different. Therefore we discuss results of the different patient groups in detail separately.

\section{HUMIDIFIER FEVER}

Preintervention and postintervention data in this study confirm the mild character of humidifier fever. There was no difference between spirometry at diagnosis and at follow up. This is not surprising because normal spirometry is one of the diagnostic criteria of humidifier fever and differentiates it from humidifier lung. ${ }^{7}$ In the humidifier fever group, compared with the other patient groups, sickness absence due to respiratory symptoms before intervention was lower, the period between the start of symptoms and diagnosis was the shortest, and the first sign was mostly reported in the free consultation hour.

Probably the rather acute presentation of humidifier fever with clearly work related phenomena is easily recognised by both the worker and the occupational physician. All three patients with humidifier fever who had hyperresponsive airways at diagnosis had a normal reaction at follow up. This is in accordance with findings after exposure to toxic organic dust $^{89}$ and could be explained by reversible inflammation caused by inhalation of endotoxins..$^{10}$ However, signs of airway inflammatory reaction have also been shown in workers without hyperresponsiveness exposed to organic dust. ${ }^{11}$

\section{HUMIDIFIER LUNG}

The four patients with a restrictive defect, a sign of allergic alveolitis, also presented a more favourable outcome at follow up than the eight patients with an obstructive defect. Spirometry returned to normal whereas mean $\mathrm{FEV}_{1}$ of the obstructive group remained well below the predicted value. Two patients with a restrictive defect who had increased airway responsiveness at diagnosis (histamine threshold 4 $\mathrm{mg} / \mathrm{ml}$ ) had normal values $(>32 \mathrm{mg} / \mathrm{ml})$ at follow up. Airway hyperresponsiveness is a common finding in patients in the acute phase of farmers' lung. ${ }^{12}{ }^{13}$ At testing a few months later Mönkäre $e t ~ a l^{12}$ found that in most of their cases there was no response to histamine as in our two patients.

Unfortunately data on responsiveness were available only in three out of eight patients of the obstructive group at follow up. In two of them responsiveness worsened, and in one it improved to a normal value $(>32 \mathrm{mg} / \mathrm{ml})$. It might be expected that because of the lower $\mathrm{FEV}_{1}$ in other patients of this group increased responsiveness would have been present at follow up.

Follow up studies in patients with farmers' lung or pigeon lung showed recovery of lung function despite continued exposure. ${ }^{14-16} \mathrm{How}-$ ever, Mönkäre and Haahtela ${ }^{16}$ found that $65 \%$ of the patients with farmers' lung still had res- piratory symptoms after 5 years of follow up, especially in those who remained hyperresponsive. Also Du Wayne Schmidt et a $l^{17}$ concluded that long term exposure to pigeon antigens will result in accelerated decline in pulmonary function in symptomatic people.

Duration of exposure has been found to have a predictive value on the prognosis of avian hypersensitivity pneumonitis. ${ }^{18}$ Because we are not sure if years of employment at the departments with humidifier antigen correspond to years of exposure to antigen, we did not have the opportunity to study this possible prognostic factor.

Kokkarinen et $a l^{14}$ suggested that patients who have had an episode of farmers' lung have an increased risk of developing subsequent asthma. Their asthmatic patients did not have asthma at the time of diagnosis of farmers' lung, by contrast with our patients who already had an asthmatic response at diagnosis and were therefore considered as having occupational asthma as in the study of Burge et al. ${ }^{19}$ However, in at least three of them an asthmatic response was accompanied by systemic reactions (increase of body temperature or white blood cell count) at workplace inhalation challenge.

Because the mean period between the start of symptoms and diagnosis in the obstructive group was $>1$ year, it is possible that they have gradually developed asthma after they had started having an alveolar response.

The disease pattern in our patients with humidifier disease emphasises the statement of Rose and King $^{20}$ that hypersensitivity pneumonitis is not a single uniform disease but a complex syndrome characterised by a variable clinical presentation and natural history.

WORK RELATED ASTHMA

All patients of this group reported work related dyspnoea, and peak flow or spirometric recording at work were suggestive of an asthmatic response in at least $64 \%$ of them $(18 \%$ borderline positive, $14 \%$ negative response). However, from studying medical records and interviewing patients at follow up, differentiation between occupational asthma or work aggravated asthma ${ }^{21}$ was not always possible. Those who did not have a pre-employment history of respiratory disease such as asthma or bronchitis obviously can be classified as having occupational asthma.

A history of asthma, however, does not exclude the diagnosis of occupational asthma. ${ }^{22}$ The exposure which caused the work related respiratory symptoms in this group could not be clearly established because we did not have data on skin tests, serology, or specific challenges. Both oil mist ${ }^{23}$ and humidifier antigens are possible causal agents.

The clinical follow up data of the work related asthma group (IV) and to a lesser extent of the patients with obstructive type of humidifier lung were in accordance with the less favourable prognosis which has been found in different studies of patients with occupational asthma. ${ }^{24}$ 
Only a few patients with work related asthma (IV) were symptom free, spirometry was improved but still showed signs of obstruction, and airway hyperresponsiveness persisted in most of the patients. Eight patients required daily medication at follow up.

Long duration of exposure and long duration of symptoms before diagnosis are determinants of a less favourable prognosis. ${ }^{24}$

In our analysis of data from the patients with an obstructive impairment (II+IV) we found an association between these variables and the levels of FVC and $\mathrm{FEV}_{1}$ at diagnosis, but not of changes in FVC and $\mathrm{FEV}_{1}$ at follow up. However, although the patients within the categories with the longest lag time and duration of exposure had the lowest mean level of FEV and $\mathrm{FEV}_{1}$, they differed most from patients belonging to the middle group of lag time and duration of exposure, and less from those in the group with the shortest period. This might point to separate clinical manifestations within the group of patients with obstructive airway disease, a fast developing type of work related asthma versus an insidious one. The fast type is expected to be more reversible. However, although patients from the group with the shortest lag time showed most increase of $\mathrm{FEV}_{1}$ at follow up their difference from the other lag time groups was not significant.

Patients with a pre-employment history of respiratory disease had a significantly lower $\mathrm{FEV}_{1}$ at diagnosis. This subgroup may contain patients with work aggravated asthma who would be expected to show more increase in $\mathrm{FEV}_{1}$ at follow up after intervention because of the supposed, more reversible character of their obstructive impairment. Indeed their changes in $\mathrm{FEV}_{1}$ and FVC were greater but the differences from patients with no pre-employment history were not significant (table 3 ).

Airway responsiveness did not improve more in those with no pre-employment history than in those who did. It was also found that airway hyperresponsiveness persisted at follow up in cases of toluene di-isocyanate asthma, ${ }^{25}$ red cedar asthma, ${ }^{26}$ asthma at a snowcrab processing factory, ${ }^{27}$ and potroom asthma. ${ }^{28}$ Therefore persistence of hyperresponsiveness does not allow differentiation between work aggravated asthma and occupational asthma. Even our finding of worsening airway responsiveness in two patients without respiratory symptoms at follow up is not unusual. ${ }^{25}$ Paggiaro et $a l^{25}$ suggested that persistence of airway hyperresponsiveness long after the end of exposure might be due to mechanisms other than inflammation.

To study the effect of removal from further exposure we should ideally have made a comparison with follow up data from patients who remained exposed or patients with asthma working in an exposure free department. However, we think that despite the lack of these data we can conclude that the intervention was successful. Spirometry of patients with work related asthma who remain exposed is not likely to improve. ${ }^{24}$
WORKING SITUATION

Despite the less favourable clinical situation of the patients with asthmatic signs (II+IV) at follow up most $(77 \%)$ were still at work, all but one in another department. Their sickness absence due to respiratory symptoms had greatly decreased. At large production sites with more plants there are normally more opportunities to transfer patients to another department. This might be the most likely explanation for the better tertiary prevention results than those of Venables et al. ${ }^{29}$

Transferring to another department, as occurred in our study, did not result in loss of income, whereas in the study of Gannon et al, income in those who became "disabled" by asthma was reduced by more than $30 \% .^{30}$

In The Netherlands, workers at small factories are at greater risk in becoming unemployed because of disability, which can only partly be explained by worse working conditions. ${ }^{31}$

Recent changes in the Dutch social security system, which places greater financial responsibility on the employer in cases of sickness absence of their workers, will obviously diminish the chance of workers with asthma finding a new job.

At follow up seven patients $(15 \%)$ received a disability pension. In two of them it was because of musculoskeletal disease and in the other five $(11 \%)$ their respiratory disease was considered to be the cause of disability. However, as has already been suggested in other studies, ${ }^{32} 33$ it remains questionable whether it was the seriousness of the impairment in their lung function that has prevented them from returning to work.

\section{SECONDARY PREVENTION}

In all but four patients the first sign of work related disease was noticed during consultations with the occupational physician. At the departments where the patients came from, workers did not undergo periodic lung examinations. After two outbreaks of humidifier disease cross sectional studies were performed before remedial actions were taken. Although significant differences were found between exposed and non-exposed workers for different variables, ${ }^{34}$ no new patients meeting the diagnostic criteria of humidifier disease were found.

It seems logical to expect that periodic screening procedures, as recommended by others, will recognise patients as early as possible. ${ }^{343}$ Screening procedures (frequency, instruments) have to be adapted to the natural history of the work related lung disease, which may be different between various agents of occupational asthma. ${ }^{36}$ Also there may be delays in reporting illness because workers might wait until the next periodic examination instead of visiting the physician during the consultation hour. Moreover predictive value of the screenings tests - such as questionnaires ${ }^{37}$ and spirometry $^{38}{ }^{39}$-or immunological tests ${ }^{40}$ are less satisfactory, or even too low to be used.

Therefore, possibly with the exception of patients in the work related asthma group with a long lag time and low $\mathrm{FEV}_{1}$ at diagnosis, it is 
unlikely that our patients would have benefited from periodic screening.

\section{Conclusion}

Follow up in patients with work related respiratory symptoms after removal from further exposure in departments with contaminated humidification systems and oil mists showed a better clinical outcome in patients with humidifier fever and humidifier lung, characterised by restrictive impairment, than in patients with humidifier lung characterised by obstructive impairment and patients with work related asthma.

Patients with work related respiratory disease may stay at work, have less sickness absence, and become less disabled by their respiratory disease when there is an opportunity for them to transfer to an exposure free department.

There is a need to evaluate the effectiveness of secondary preventive activities in occupational health.

It still has to be investigated whether clear (periodic) information given to the workers about possible risks at work, a readily accessible consultation hour, and prompt action if sickness absence due to respiratory disease is repeated lead to more effective secondary prevention of work related respiratory disease than screening procedures.

We are indebted to Peter Hol, Franko de Wolff, Tiny de Boer, Jildou Pal, and Jan Coenraads for their assistence in gathering and analysing the data and performing the follow up investigation in the patients.

1 Dolovich J, Hargreave F. The asthma syndrome: inciters, inducers and host characteristics [editorial]. Thorax 1981;36:641-4.

2 Pal TM, de Monchy JGR, Groothoff JW, et al. The clinical spectrum of humidifier disease in synthetic fiber plants. A $m$ spectrum of humidifier dise

3 Kateman E, Heederik D, Pal TM, et al. Relationship of airborne microorganisms with lung function and leucocyte levels of workers with a history of humidifier fever. Scand $\mathcal{F}$ Work Environ Health 1990;16:428-33.

$4 \mathrm{Pal}$ TM, Kauffmann HF, de Monchy JGR, et al. Lung function of workers exposed to antigens from a contaminated airconditioning system. Int Arch Occup Environ Health 1985;55:253-66.

5 Costongs GMPJ, Janson PCW, Bos BM. Short-term and long-term intraindividual variations and critical differences of haematological laboratory parameters. $\mathcal{F}$ Clin Chem Clin Biochem 1985;23:69-76.

6 Kremer AM, Pal TM, Oldenziel M, et al. The use and safety of a shortened histamine challenge test in an occupational health study. Eur Respir 7 1995;8:737-44.

7 Baur X, Behr J, Dewair M, et al. Humidifier lung and humidifier fever. Lung 1988;166:113-24.

8 Malmberg P, Larsson K. Acute exposure to swine dust Malmberg P, Larsson K. Acute exposure to swine dust
causes bronchial hyperresponsiveness in healthy workers. causes bronchial hyperrespon
Eur Respir F 1993;6:400-4.

9 Amishima M, Munakata M, Ohtsuka Y, et al. Dairy farmers have increased methacholine bronchial responsiveness independent of sensitization to mold antigens. Am 7 Crit Care Med 1995;141:1794-8.

10 Rylander R, Bake B, Fisher J, et al. Pulmonary function and symptoms after inhalation of endotoxin. Am Rev Respir Di 1989;140:981-6.

11 Larsson K, Aklund A, Malmberg P, et al. Alterations in bronchoalveolar lavage fluid but not in lung function and bronchial responsiveness in swine confinement workers. Chest 1992:101:767-74.

12 Monkäre S, Haahtela T, Ikonen M, et al. Bronchial hyperreactivity to inhaled histamine in patients with farmers lung. Lung 1981;159:145-51.

13 Friedman PM, Ault B. Bronchial hyperreactivity to methacholine in farmers lung disease. F Allergy Clin Immunol $1981 ; 67: 59-63$.

14 Kokkarinen JI, Rukiainen HO, Terho EO. Recovery of pulmonary function in farmers lung: a five year follow-up study. Am Rev Respir Dis 1993;147:793-6.

15 Bourke SJ, Banham SW, Carter R, et al. Longitudinal course of extrinsic allergic alveolitis in pigeon breeders. Thorax 1989;44:415-18.

16 Monkäre S, Haahtela T. Farmers lung: a 5 year follow-up of eighty-six patients. Clin Allergy 1987;17:143-51.

17 Du Wayne Schmidt L, Jensen RL, Christensen LT, et al. Longitudinal pulmonary function changes in pigeon breeders. Chest 1988;93:359-63.

18 Gracia de J, Morell F, Bofill JM, et al. Time of exposure as a prognostic factor in avian hypersensitivity pneumonitis. Respir Med 1989;83:139-43.

19 Burge PS, Finnegan M, Horsfield N, et al. Occupational asthma in factory with a contaminated humidifier. Thorax 1985;40:258-4.

20 Rose C, King TE. Controversies in hypersensitivity pneumonitis. Am Rev Respir Dis 1992;145:1-2.

21 Chan-Yeung M, Malo JL. Occupational asthma. N Engl f Med 1995;333:107-11.

22 Cartier A. Definition and diagnosis of occupational asthma. Eur Respir F 1994;7:153-60.

23 Robertson AS, Weir DC, Burge PS. Occupational asthma due to oil mists. Thorax 1988;43:200-5.

24 Paggiaro PL, Vagaggini B, Bacci E, et al. Prognosis in occupational asthma. Eur Respir f 1994;7:761-7.

25 Paggiaro PL, Loi AM, Rossi O, et al. Follow-up study of patients with respiratory disease due to toluene diisocyanate (TDI). Clin Allergy 1984;14:463-9.

26 Chan-Yeung M, Lam S, Koenen S. Clinical features and natural history of occupational asthma due to western red cedar. Am f Med 1982;72:411-15.

27 Allard C, Cartier A, Ghezzo H, et al. Occupational asthma due to various agents. Absence of clinical and functional improvement at an interval of four or more years after cessation of exposure. Chest 1989;5:1046-9.

28 Saric M, Marelja J. Bronchial hyperreactivity in potroom workers and prognosis after stopping exposure. $B r \mathcal{F}$ Ind Med 1991;48:653-5

29 Venables KM, Davison AG, Newman Taylor AJ. Consequences of occupational asthma. Respir Med 1989;83:43740

30 Gannon PFG, Weir D, Robertson AS, et al. Health employment and financial outcome in workers with occupational asthma. Br F Ind Med 1993;50:491-6.

31 Knepper S, Croon NHTH. Arbeidsongeschiktheid in Nederland: Een gezondheidskundige balans. (In Dutch.) Ned Tijdschr Geneeskd 1991;135:267-72.

32 Ames RG, Trent RB. Respiratory impairment and symptoms as predictors of early retirement with disability in US underground coal miners. Am 7 Public Health 1984;74 837-8.

33 Pearce SJ, Rosner V, Robinson AJ, et al. Invalidity due to chronic bronchitis and emphysema: how real is it. Thorax 1985;40:828-31.

$34 \mathrm{Harber} \mathrm{Ph}$. Prevention and control of occupational lung disease. Clin Chest Med 1981;2:343-55.

35 Venables KM, Prevention of occupational asthma. Eur Respir 7 1994;7:768-78.

36 Malo JL, Ghezzo H, D'Aguino C, et al. Natural history of occupational asthma: relevance of type of agent and other factors in the rate of development of symptoms in affected subjects. F Allergy Clin Immunol 1992;90:937-44

37 Malo JL, Ghezzo H, L'Archevêque J, et al. Is the clinical history a satisfactory means of diagnosing occupational asthma. Am Rev Respir Dis 1991;143:528-32.

38 Burge PS. Single and serial measurements of lung function in the diagnosis of occupational asthma. Eur $\mathcal{F}$ Respir Dis 1982;63S: $47-59$.

39 Post WK, Steijerberg E, Burdory A, et al. Choosing optimal values of $\mathrm{FEV}_{1}$ and $\mathrm{FEV}_{1} / \mathrm{FVC}$ for surveillance for respiratory disorders in occupational populations. F Occup Environ Med 1996;38:673-80.

40 Venables KM, Dally MB, Nunn AJ, et al. Smoking and occupational allergy in a platinum refinery. $B M \mathcal{F} 1989 ; 299$ : 939-42. 